\title{
KEMANDIRIAN PETANI DALAM BERUSAHATANI SAGU DI DESA TANJUNG KECAMATAN TEBING TINGGI BARAT KEBUPATEN KEPULAUAN MERANTI PROVINSI RIAU
}

\author{
Rahmat Nursodik ${ }^{1}$, Rosnita ${ }^{2}$, Eri Sayamar ${ }^{2}$ \\ 1. Mahasiswa Fakultas Pertanian Universitas Riau \\ 2. Dosen Fakultas Pertanian Universitas Riau \\ Jurusan Agribisnis Fakultas Pertanian Universitas Riau \\ E-mail: Rahmat.nursodik@yahoo.com
}

\begin{abstract}
: in the globalization era, farmers should have strong independence and competitiveness. They have to be able to manage their agribusiness to ensure product quality and sustainable agribusiness. The objectives of the research are: to analyze the independence sago farmers in farming in the village of Tanjung, This research was conducted in the village of Tanjung District of Tebing Tinggi Barat Meranti Islands District. 66 farmers serve as respondents to the capture technique respondents using purposive sampling method. Data collected by observation, interviews, and questionnaires. analysis methods used to answer the objectives in this research is methods Likert Scale's Analysis. The results showed: The Independence of farmers in farming sago in the village of Tanjung is independent.
\end{abstract}

Keywords: farmer, independence,

\begin{abstract}
Abstrak: Kesiapan menghadapi era globalisasi membutuhkan kemandirian petani dalam daya saing, hal ini berkaitan dengan kemandirian petani dalam me-manage usahataninya guna menjamin kualitas produk dan keberlanjutan usahatani. Tujuan penelitian ini adalah: untuk menganalisis kemandirian petani sagu di Desa Tanjung. Penelitian dilakukan menggunakan metode survey di Desa Tanjung Kecamatan Tebing Tinggi Barat Kabupaten Kepulauan Meranti mulai dari Bulan Maret 2016 sampai Agustus 2016. Pengambilan sampel dilakukan secara Purposive Sampling dengan pertimbangan petani melakukan usahatani sagu dan tergabung dalam kelompok tani yang masih aktif, dari 210 petani diambil 66 petani. Metode analisis yang digunakan adalah Deskriptif dan Skala Likert. Hasil penelitian menunjukkan bahwa petani sudah mandiri dalam berusahatani sagu yang ditunjukkan dengan nilai skor 3,75. Kemandirian tertinggi diperoleh pada kemandirian mencari informasi yang didukung kepemilikan dengan komunikasi (handphone). Kemandirian dalam menentukan harga berada pada posisi paling rendah karena tingkat ketergantungan petani dengan toke yang sangat tinggi sehingga toke lebih berperan dalam penentuan harga.
\end{abstract}

Kata Kunci: petani, kemandirian.

\section{PENDAHULUAN}

Indonesia tercatat sebagai salah satu negara penghasil sagu terbesar di dunia di mana 60 persen sagu dihasilkan dari wilayah yang tersebar di Provinsi Papua, Papua Barat, Maluku, Sulawesi, Kalimantan, Sumatera, Kepulauan Riau dan Kepulauan Mentawai.
Pengembangan sagu di Indonesia bertujuan untuk mendukung pelaksanaan Inpres No.20 tahun 1979 tentang usaha diversifikasi pangan, sebab sagu di Indonesia disamping potensi produksinya tinggi, sagu berpeluang besar dipakai sebagai makanan yang disukai masyarakat. 
Pengembangan sagu di Riau khususnya di Kabupaten Kepulauan Meranti bertujuan untuk mengoptimalkan sumberdaya sagu dan menjaga pengolahan hasil secara berkelanjutan serta mendorong terwujudnya usaha pengolahan sagu yang efesien, efektif dan berdaya saing yang didukung oleh subsistem off farm, terutama pengolahan dan pemasaran hasil industri hilir yang memadai sehingga dapat memberikan manfaat yang optimal bagi semua pihak.

Gubernur Riau telah menobatkan bahwa Kabupaten Kepulauan Meranti sebagai pusat pengembangan tanaman sagu secara nasional. Desa Nipah Sendanu dan Sungai Tohor merupakan penghasilan sagu terbesar di Indonesia dengan kapasitas produksi sagu basah sekitar 500 ton/bulan. Menurut data Dinas Perkebunan Kabupaten Kepulauan Meranti (2014), luas area tanaman sagu di Kabupaten Kepulauan Meranti mencapai 38,399 Ha yaitu 2,98 persen luas tanaman sagu Nasional. Perkebunan sagu di Kabupaten Kepulauan Meranti telah menjadi sumber penghasilan utama dengan produksi sagu mencapai 198,162 ton/th dan terdapat 67 kilang sagu.

Sagu di Kabupaten Kepulauan Meranti tersebar di berbagai Kecamatan termasuk, Kecamatan Tebing Tinggi Barat. Menurut data Dinas Perkebunan Kabupaten Kepulauan Meranti (2014) di Kecamatan Tebing Tinggi Barat terdapat 14 desa dan hanya enam desa yang membudidayakan sagu dengan jumlah luas 9.017 ha dengan produksi sagu mencapai 61,317 ton/thn. Di Kecamatan Tebing Tinggi Barat desa yang berproduksi sagu tertinggi adalah Desa Tanjung dengan luas lahan sagu mencapai 6,526 ha dengan produksi sagu mencapai 44,100 ton/thn.

Rosnita dkk (2016), menjelaskan bahwa pertumbuhan penduduk yang tinggi, berkurangnya lahan pertanian akibat alih fungsi lahan merupakan pemicu kerawanan pangan yang mengancam kepada ketahanan pangan yang terjadi. Dampak tersebut dapat dilihat dari kondisi ekonomi yang tidak stabil, gizi buruk, penduduk miskin yang bertambah serta lajunya pertumbuhan penduduk yang tidak seimbang dengan ketersediaan pangan. Petani sagu di Kecamatan Tebing Tinggi Barat sebagai pelaku utama yang menjadi ujung tombak dalam ketersediaan sagu memiliki tanggung jawab dalam meningkatkan kesejahteraan petani dan keluarganya diharapkan mandiri dalam melakukan usahatani sagu yang dimulai dari penentuan jenis sagu hingga mandiri dalam memasarkan sagu yang dihasilkan.

Mulyandari (2001), menjelaskan bahwa petani yang mandiri adalah petani yang dalam upaya meningkatkan kualitas hidupnya (kesejahteraan keluarga dan masyarakatnya) tidak hanya bersandar/bergantung pada petunjuk dari penyuluh, aparat atau pihak lain, tetapi lebih bersandar pada kemampuan mengambil keputusan sendiri secara tepat dan kekuatan sendiri yang didorong oleh motivasinya untuk meningkatkan kualitas kehidupannya. Kemandirian anggota kelompok tani tersebut dapat dilihat dari, yaitu (1) mandiri dalam pemilihan jenis komoditi yang diusahakan, (2) Penentuan harga komoditi yang dihasilkan, (3) Akses terhadap sarana produksi pertanian, (4) mandiri dalam bekerja sama, (5) mandiri untuk mencari informasi dan (6) Pengetahuan dalam berusahatani.

Rumusan masalah dalam penelitian ini adalah: Seberapa besar kemandirian petani dalam berusahatani sagu di Desa Tanjung Kecamatan Tebing Tinggi Barat Kabupaten Kepulauan Meranti.

Tujuan penelitian ini adalah untuk menganalisis tingkat kemandirian petani dalam berusahatani sagu di Desa Tanjung Kecamatan Tebing Tinggi Barat Kabupaten Kepulauan Meranti.

\section{METODE PENELITIAN}

\section{Tempat dan Waktu Penelitian}

Penelitian ini dilaksanakan di Desa Tanjung Kecamatan Tebing Tinggi Barat Kabupaten Kepulauan Meranti. Alasan memilih lokasi ini berdasarkan pertimbangan bahwa Desa Tanjung merupakan salah satu desa yang memiliki perkebunan sagu terluas yang ada di Kecamatan Tebing Tinggi Barat dan memiliki jumlah kelompok tani sagu terbanyak serta aktif dalam berusahatani sagu. Penelitian ini dimulai dari Bulan Maret 2016 sampai dengan Agustus 2016, meliputi survey lapangan, pengumpulan data, penulisan dan penyusunan hasil penelitian hingga penyelesaian skripsi. 


\section{Metode Pengambilan Sampel dan Data}

Penelitian ini menggunakan metode survey yaitu melakukan penelitian untuk memperoleh fakta-fakta informasi secara faktual.

Populasi dalam penelitian ini adalah petani yang menjadi anggota kelompok tani sagu di Desa Tanjung Kecamatan Tebing Tinggi Barat Kabupaten Kepulauan Meranti yang berjumlah 210 orang dari delapan kelompoktani yang aktif serta kurang aktif dalam berusahatani sagu.

Teknik pengambilan responden menggunakan cara Purposive Sampling (sengaja). Teknik ini bisa diartikan sebagai suatu proses pengambilan responden dengan menentukan terlebih dahulu jumlah responden yang hendak diambil, kemudian pemilihan responden dilakukan dengan berdasarkan tujuan-tujuan tertentu (Sugiyono, 2009) dengan pertimbangan yaitu petani yang tergabung dalam kelompok tani yang masih aktif. Berdasarkan informasi dari Unit Pelaksana Teknis Daerah, diketahui sekitar 210 petani yang bergabung kedalam kelompok tani di Desa Tanjung Kecamatan Tebing Tinggi Barat.

Dalam penelitian ini ada dua jenis sumber data, yaitu data primer dan data sekunder. Data primer, yaitu data yang diperoleh dengan melakukan wawancara langsung kepada informan dengan berpedoman pada kuesioner dengan daftar pertanyaan yang telah disiapkan agar terjawab tujuan penelitian. Sedangkan Data sekunder diperoleh dari instansi yang terkait, seperti: Badan Pusat Statistik Provinsi Riau, Balai Pertanian Kecamatan dan UPTD, Dinas Kependudukan Dan Pencatatan Sipil Kecamatan Tebing Tinggi Barat.

Teknik pengumpulan data yang perlu dalam penelitian ini dilakukan dengan berbagai cara, yakni sebagai berikut:

1) Teknik observasi, yaitu teknik pengumpulan data yang dilaksanakan dengan jalan mengadakan pengamatan langsung pada objek yang diteliti.

2) Teknik wawancara, yaitu pengumpulan data yang diperoleh dengan bertanya langsung kepada informan menggunakan daftar pertanyaan tertulis, data yang diperoleh dipergunakan sebagai data primer.
3) Kuesioner, yaitu alat bantu sebagai pedoman untuk wawancara dalam pengumpulan data dengan responden.

4) Teknik pencatatan, yaitu mencatat data yang diperlukan serta ada hubungannya dengan penelitian ini yang ada diinstansi terkait.

\section{Analisis Data}

Metode analisis data yang digunakan untuk menjawab tujuan pada penelitian ini adalah:Analisis, Skala Likert's,

\section{Skala Likert's}

Menurut Sugiyono (2009) Skala likert digunakan untuk mengukur sikap, pendapat dan persepsi seseorang atau sekelompok tentang kejadian atau gejala sosial. Dalam penelitian gejala sosial telah ditetapkan secara spesifik oleh peneliti yang selanjutnya disebut sebagai variabel penelitian. Nilai skala jawaban tertutup dari responden dibuat dalam bentuk pernyataan positif (jawaban yang diharapkan) diberi nilai lima (5) hingga pernyataan negatif (jawaban yang tidak diharapkan) diberi nilai satu (1).

Maka digunakan scale likert's summated rating (SLR) nilai sekala untuk masing-masing jawaban yang di berikan responden dapat dilihat pata Tabel 1. Dari total nilai pokok skala dikelompokkan menjadi lima kategori persepsi yang dapat dihitung dengan menggunakan rumus. Rentang penilaian berkisar 1-5, yaitu penilaian tertinggi, rentang skala penelitian ini dihitung sebagai berikut :

$$
\text { Rentang Skala }=\frac{5-1}{5}-0,01=0,79
$$

Berdasarkan kisaran diatas, maka tingkatan untuk mengetahui kemandirian petani dalam berusahatani sagu dapat dilihat pada Tabel 2.

Tabel 1. Nilai skala jawaban yang diberikan responden

\begin{tabular}{lc}
\hline \multicolumn{1}{c}{ Kemandirian Petani } & Nilai Skala \\
\hline Sangat Mandiri & 5 \\
Mandiri & 4 \\
Cukup Mandiri & 3 \\
Kurang Mandiri & 2 \\
Sangat Kurang Mandiri & 1 \\
\hline Sumber: Mulyandari, $(2001)$ &
\end{tabular}


Tabel 2. Nilai skala kategori kemandirian petani sagu

\begin{tabular}{lc}
\hline \multicolumn{1}{c}{ Kemandirian Petani } & Nilai Skala \\
\hline Sangat Mandiri & $4,20-5,00$ \\
Mandiri & $3,40-4,19$ \\
Cukup Mandiri & $2,60-3,39$ \\
Kurang Mandiri & $1,80-2,59$ \\
Sangat Kurang Mandiri & $1,00-1,79$ \\
\hline
\end{tabular}

Sumber: Mulyandari, (2001)

\section{HASIL DAN PEMBAHASAN}

\section{Profil Daerah Penelitian}

Desa Tanjung memiliki luas lahan sagu mencapai 6,526 ha denganproduksi sagu mencapai 44,100 ton/ thn dengan jumlah petani sagu 271 orang dan memiliki kilang sagu sebanyak 15 kilang.

Desa Tanjung merupakan salah satu dari 14 (empat belas) desa di Kecamatan Tebing Tinggi Barat Kabupaten Kepulauan Meranti. Desa Tanjung memiliki luas wilayah seluas $4.710 \mathrm{~km}^{2}$ dengan jumlah penduduk 1.108 jiwa yang tersebar di 4 dusun yaitu Dusun Lalang, Dusun Lalang-suir, Dusun Tanah Merah dan Dusun Tanah Merah Barat.

Jika ditinjau secara administratif Desa Tanjung termasuk dalam wilayah Kecamatan Tebing Tinggi Barat Kabupaten Kepulauan Meranti. Jarak antara Desa Tanjung dengan pusat pemerintahan Ibukota Kecamatan Tebing Tinggi Barat $\pm 18 \mathrm{Km} / 0,5 \mathrm{Jam}$, dan jarak antara Desa Tanjung dengan pusat pemerintahan Ibukota Kabu-paten Kepulauan Meranti sejauh $\pm 18 \mathrm{Km} / 0,5 \mathrm{Jam}$.

Secara umum wilayah Desa Tanjung sebagian besar bertopografi datar dengan kelerengan $0-8$ persen dengan ketinggian rata-rata 1- 7 meter di atas permukaan laut. Sagu dapat tumbuh sampai ketinggian $700 \mathrm{~m}$ di atas permukaan laut, namun produksi sagu terbaik ditemukan sampai ketinggian $400 \mathrm{~m}$ di atas permukaan laut. Berdasarkan uraian tersebut dan hasil penelitian dapat disimpulkan bahwa Desa Tanjung merupakan daerah yang berpotensi untuk perkebunan sagu.

\section{Identitas Petani Responden}

Identitas responden merupakan salah satu aspek penting yang turut berpengaruh dalam pendapatan usahataninya. Identitas responden dapat memberikan gambaran secara umum mengenai kondisi dan kemampuan dalam mengelola usahanya, melakukan aktivitas ekonomi dan non ekonomi kepala keluarga tidak terlepas dari kualitas sumber daya manusia itu sendiri yang dipengaruhi oleh beberapa faktor seperti umur, tingkat pendidikan, jumlah tanggungan keluarga, pengalaman berusaha tani dan luas lahan yang dimiliki.

Petani yang menjadi objek penelitian ini adalah petani sagu pola swadaya di Desa Tanjung Kecamatan Tebing Tinggi Barat Kabupaten Kepulauan Meranti, sampel diambil di Desa Tanjung dengan jumlah sampel 66 orang petani. Karakteristik petani diperlukan untuk melihat beberapa hal yang menjadi dasar pertimbangan dalam menggambarkan keadaan petani sagu secara jelas.

Karakteristik tersebut dapat dilihat dari jenis kelamin, umur, tingkat pendidikan, jumlah tanggungan keluarga, pengalaman

Tabel 3. Identitas Petani Responden

\begin{tabular}{|c|c|c|c|}
\hline \multirow{2}{*}{$\begin{array}{l}\text { No } \\
1 .\end{array}$} & Kriteria & $\mathrm{N}$ & $\%$ \\
\hline & $\begin{array}{l}\text { Umur responden } \\
\text { a. Produktif }(15-55) \\
\text { b. Non Produktif }(>55)\end{array}$ & $\begin{array}{r}57 \\
9\end{array}$ & $\begin{array}{r}86 \\
13,7\end{array}$ \\
\hline & Jumlah & 66 & 100 \\
\hline 2. & Tingkat pendidikan & & \\
\hline & $\begin{array}{l}\text { a. Tidak tamat SD } \\
\text { b. SD }\end{array}$ & $\begin{array}{r}3 \\
32\end{array}$ & $\begin{array}{r}4,5 \\
48,5\end{array}$ \\
\hline & c. SMP & 21 & 31,8 \\
\hline & d. SMA & 9 & 13,6 \\
\hline & e. Perguruan tinggi & 1 & 1,5 \\
\hline & Jumlah & 66 & 100 \\
\hline
\end{tabular}




\begin{tabular}{|c|c|c|c|}
\hline \multirow[t]{6}{*}{3.} & \multicolumn{3}{|l|}{ Pengalaman usaha-tani } \\
\hline & a. $0-5$ & 9 & 13,6 \\
\hline & b. $6-10$ & 13 & 19,7 \\
\hline & c. $11-15$ & 17 & 25,8 \\
\hline & d. $16-20$ & 16 & 24,2 \\
\hline & e. $>20$ & 11 & 16,7 \\
\hline \multicolumn{2}{|r|}{ Jumlah } & 66 & 100 \\
\hline \multirow[t]{5}{*}{4.} & Luas Lahan & & \\
\hline & a. $\operatorname{Luas}(>2)$ & 11 & 16,7 \\
\hline & b. Sedang (0,5-2 ha) & 55 & 83,3 \\
\hline & c. Sempit $(<5$ ha $)$ & - & - \\
\hline & Jumlah & 66 & 100 \\
\hline \multirow[t]{5}{*}{5.} & $\begin{array}{l}\text { Jumlah tanggungan keluarga } \\
\text { a. } 0-3\end{array}$ & & \\
\hline & b. $4-6$ & 41 & 62,1 \\
\hline & c. $>6$ & 23 & 34,8 \\
\hline & & 2 & 3 \\
\hline & Jumlah & 66 & 100 \\
\hline
\end{tabular}

Sumber: Data monografi Desa Tanjung Kecamatan Tebing Tinggi Barat 2014.

berusahatani perkebunan sagu. Identitas petani responden dapat dilihat pada Tabel 3 .

Tabel 3 menggambarkan, mayoritas petani sagu di Desa Tanjung yang menjadi responden dalam penelitian ini adalah: memiliki usia produktif (15-55 tahun) sebesar $86 \%$, mayoritas memiliki tingkat pendidikan SD sebesar $48,5 \%$, pengalaman usahatani 11 15 tahun sebesar $25,8 \%$, memiliki luas lahan sedang (0,5-2) sebesar $83,3 \%$, dan memiliki jumlah tanggungan keluarga 0-3 orang sebesar $62,1 \%$.

\section{Kemandirian Petani dalam Berusa-hatani Sagu}

Variabel penelitian yang digunakan dalam penelitian ini diperoleh dari hasil studi pustaka terhadap hasil penelitian terdahulu yang memiliki keterkaitan dengan tingkat kemandirian petani, di antaranya: Subagio (2008) mengemukakan bahwa kemandirian petani dalam berusa hatani sayuran dan padi di Provinsi Jawa Timur dipengaruhi secara nyata oleh karakteristik petani, ketersediaan inovasi, dukungan lingkungan sosial budaya, kapasitas petani dan kedinamisan usahatani; Anantanyu (2008) menyatakan bahwa kemampuan petani merupakan faktor penentu dalam mewujudkan kemandirian petani di Provinsi Jawa Tengah. Selain itu, Ediningtyas (2007) menyebutkan kemandirian petani dalam usahatani agroforestri program kemitraan petani dengan PT. Perhutani Unit III di Kecamatan Ciwidey, Kabupaten Bandung, Jawa Barat dipengaruhi oleh faktor dukungan dari luar petani, tingkat pendidikan dan pengalaman usahatani.

Lebih lanjut menurut Mulyandari (2001), menjelaskan bahwa petani yang mandiri adalah petani yang dalam upaya meningkatkan kualitas hidupnya (kesejahteraan keluarga dan masyarakatnya) tidak hanya bersandar/ bergantung pada petunjuk dari penyuluh, aparat atau pihak lain, tetapi lebih bersandar pada kemampuan mengambil keputusan sendiri secara tepat dan kekuatan sendiri yang didorong oleh motivasinya untuk meningkatkan kualitas kehidupannya.

Kemandirian petani dilihat berdasarkan beberapa sub variabel yaitu kemandirian dalam pemilihan jenis komoditi yang diusahakan, penentuan harga komoditi yang dihasilkan, akses sarana produksi pertanian, kemampuan dalam bekerja sama, kemampuan untuk mencari informasi, dan pengetahuan dalam berusahatani.

\section{Kemandirian dalam Pemilihan Jenis Komoditi yang Diusahakan}

Lestari (2011), kemandirian untuk mengambil keputusan dalam pemilihan jenis komoditas, yaitu kemampuan petani untuk memilih jenis komoditas yang diusahakan. Indikatornya adalah jenis komoditas yang diusahakan, dasar pertimbangan yang digunakan dalam pemilihan jenis komoditas yang diusahakan, pihak yang terlibat dalam pemilihan jenis komoditas yang diusahakan. 
Kemandirian petani sagu dalam pemilihan komoditi yang diusahakan dapat dilihat pada Tabel 4.

Table 4. Kemandirian petani sagu dalam pemilihan komoditi yang diusaha-kan

\begin{tabular}{|c|c|c|c|}
\hline No & Indikator & Skor & Kategori \\
\hline 1. & $\begin{array}{ll}\text { Menentukan } & \text { jenis } \\
\text { komoditi } & \text { yang } \\
\text { diusahakan } & \end{array}$ & 4,10 & Mandiri \\
\hline 2. & $\begin{array}{l}\text { Dasar pertimbangan } \\
\text { dalam } \text { pemilihan } \\
\text { jenis komoditi }\end{array}$ & 4,00 & Mandiri \\
\hline 3. & $\begin{array}{l}\text { Pihak yang terlibat } \\
\text { dalam pemilihan } \\
\text { jenis komoditi }\end{array}$ & 3,41 & Mandiri \\
\hline & Rata-rata & 3,84 & Mandiri \\
\hline
\end{tabular}

Sumber: Data olahan Tahun 2016

Tabel 4 di atas menggambarkan secara keseluruhan kemandirian petani dalam pemilihan jenis komoditi sudah mandiri dengan skor rata-rata 3,84 . Hal ini berarti bahwa petani sagu di Desa Tanjung sudah mandiri dalam pemilihan komoditi yang diusahakan, artinya petani mempunyai inisiatif dan memutuskan sendiri, terutama untuk pilihan komoditi yang diusahakan.

Secara keseluruhan kemandirian petani sagu dalam pemilihan komoditi sagu tergolong kategori mandiri, namun apabila dilihat dari nilai skor masing-masing, maka skor tertinggi pada menentukan jenis komoditi yang diuasahakan. Dalam menentukan jenis komoditi yang diusahakan, petani sagu di Desa Tanjung memutuskan sendiri. Komoditi yang diusahakan diwariskan secara turun temurun pada anggota keluarga petani sagu.

Selanjutnya dasar pertimbangan dalam pemilihan jenis komoditi dengan skor 4,00. Pertimbangan dalam pemilihan jenis komoditi sangat penting untuk menentukan tingkat produksi sagu, untuk itu petani sagu di Desa Tanjung sebagian besar petani sagu memutuskan sendiri, dengan pertimbangan bahwa mereka sudah melihat hasil atas komoditi yang digunakan selama ini dari segi produksinya.

Sedangkan skor terendah pada pihak yang terlibat dalam pemilihan jenis komoditi dengan skor 3,41. Dalam pemilihan jenis komoditi, petani di Desa Tanjung tidak banyak melibatkan pihak lain, mereka memutuskan sendiri komoditi yang akan digunakan, kalaupun ada yang terlibat biasanya orang tua, anggota keluarga yang merupakan usaha turun temurun.

\section{Kemandirian untuk Mengambil Keputusan dalam Penentuan Harga}

Lestari (2011), kemandirian untuk mengambil keputusan dalam penentuan harga, yaitu kemampuan petani dalam menentukan harga komoditi yang dihasilkan. Indikatornya adalah dasar pertimbangan dalam penentuan harga komoditi dan pihak yang terlibat dalam proses penentuan harga komoditi.

Kemandirian petani dalam mengambil keputusan dalam penentuan harga dapat dilihat pada Tabel 5. Tabel 5 menggambarkan secara keseluruhan kemandirian petani dalam mengambil keputusan dalam penentuan harga cukup mandiridengan skor rata-rata 3,38. Hal ini menunjukkan bahwa petani sagu di Desa Tanjung dalam mengambil keputusan penentuan harga, petani dan toke/tengkulak yang saling tawar-menawar harga walaupun toke/tengkulak sudah menentukan/ mematok harganya.

Tabel 5. Kemandirian petani dalam mengambil keputusan

\begin{tabular}{clcc}
\hline No & \multicolumn{1}{c}{ Indikator } & Skor & Kategori \\
\hline 1. & $\begin{array}{l}\text { Dasar pertimbangan } \\
\text { dalam penentuan } \\
\text { harga komoditi }\end{array}$ & 3,36 & $\begin{array}{c}\text { Cukup } \\
\text { mandiri }\end{array}$ \\
2. & $\begin{array}{l}\text { Pihak yang terlibat } \\
\text { dalam proses } \\
\text { penentuan harga } \\
\text { komoditi }\end{array}$ & 3,39 & $\begin{array}{c}\text { Cukup } \\
\text { mandiri }\end{array}$ \\
\hline Rata-rata & 3,38 & $\begin{array}{c}\text { Cukup } \\
\text { mandiri }\end{array}$ \\
\hline
\end{tabular}

Sumber: Data olahan Tahun 2016

Secara keseluruhan kemandirian petani sagu dalam kemandirian petani untuk mengambil keputusan dalam penentuan harga tergolong kategori cukup mandiri, namun apabila dilihat dari nilai skor masing-masing indikator, maka skor tertinggi terdapat pada pihak yang terlibat dalam proses penentuan harga komoditi cukup mandiri, ini dapat dilihat dari skor yang diperoleh yaitu 3,39. Hal ini menunjukkan bahwa dalam proses penentuan harga komoditi ada pihak yang terlibat dalam 
penentuan harga komoditi, diantaranya adalah pedagang-pedagang pengumpul/ tengkulak, karena pada umumnya petani sagu di Desa Tanjung tidak menjual secara langsung ke kilang-kilang sagu, akan tetapi mereka menjual kepada tengkulak atau pedagang pengumpul.

Sedangkan nilai skor terendah terdapat pada dasar pertimbangan dalam penentuan harga komoditi dengan skor 3,36 yang tergolong kategori cukup mandiri. Hal ini menunjukkan bahwa ada dasar pertimbangan dalam penentuan harga, penentuan harga sagu di Desa Tanjung, khususnya tepung sagu dilihat dari kualitas pati, tingkat kemurnian pati, semakin tinggi kualitas pati yang dihasilkan oleh tepung sagu, semakin tinggi harganya, disamping itu biaya transportasi juga menjadi pertimbangan dalam menentukan harga, karena letak Desa Tanjung ke pabrik pengolahan sagu, aksesnya cukup sulit karena harus melewati laut. Selanjutnya yang menjadi kuasa atas harga sagu di Desa Tanjung adalah petani dan toke/ tengkulak yang saling tawarmenawar harga walaupun toke/ tengkulak sudah menentukan/mematok harganya.

\section{Kemandirian untuk Mengambil Keputusan dalam Pemenuhan Sarana Produksi}

Lestari (2011), kemandirian untuk mengambil keputusan dalam pemenuhan sarana produksi, yaitu kemampuan petani untuk mengakses sarana produksi pertanian. Indikatornya adalah menentukan akses sarana produksi, dasar pertimbangan dalam penentuan sarana produksi hasil usahatani, dan pihak yang terlibat proses penentuan sarana produksi.

Tabel 6. Kemandirian petani sagu untuk mengambil keputusan pemenuhan sarana produksi

\begin{tabular}{clcl}
\hline No & \multicolumn{1}{c}{ Indikator } & Skor & Kategori \\
\hline 1. & $\begin{array}{l}\text { Menentukan akses } \\
\text { sarana produksi }\end{array}$ & 3,50 & Mandiri \\
2. & $\begin{array}{l}\text { Dasar pertimbangan } \\
\text { dalam penentuan } \\
\text { sarana produksi hasil } \\
\text { usahatani }\end{array}$ & 3,80 & Mandiri \\
3. & $\begin{array}{l}\text { Pihak yang terlibat } \\
\text { dalam proses } \\
\text { penentuan sarana } \\
\text { produksi. }\end{array}$ & 3,88 & Mandiri \\
& & \\
\hline
\end{tabular}

Sumber: Data olahan Tahun 2016
Kemandirian petani dalam mengambil keputusan dalam menentukan sarana produksi di Desa Tanjung Kecamatan Tebing Tinggi Barat Kabupaten Kepulauaan Merantidapat dilihat pada Tabel 6.

Tabel 4 di atas menggambarkan secara keseluruhan kemandirian petani dalam mengambil keputusan dalam pemenuhan sarana produksi sudah mandiri memperoleh skor rata-rata 3,74. Hal ini membuktikan bahwa petani sagu di Desa Tanjung sudah mandiri dalam menentukan keputusannya untuk pemenuhan sarana produksi, penentuan sarana produksi hasil usahatani, serta pihak yang terlibat dalam proses penentuan sarana produksi karena informasi sarana yang akan digunakan sudah diperoleh dari orang tua/kakek (turun temurun) dan tidak tergantung kepada orang luar/toke.

Secara keseluruhan kemandirian petani sagu mengambil keputusan dalam pemenuhan sarana produksi tergolong kategori mandiri, namun apabila dilihat dari nilai skor masingmasing indikator, maka skor tertinggi terdapat pada pihak yang terlibat dalam proses penentuan sarana produksi dengan skor 3,88 yang tergolong kategiri mandiri karena dalam proses penentuan sarana produksi informasi sarana yang akan digunakan sudah diperoleh dari orang tua/kakek (turun temurun) dan tidak tergantung kepada orang luar/toke.

Selanjutnya dasar pertimbangan pihak dalam penentuan sarana produksi dengan skor 3,80 yang tergolong kategori mandiri. Dalam menentukan sarana produksi tersebut cukup banyak yang menjadi dasar pertimbangan petani sagu diantaranya adalah modal. Modal sangat dibutuhkan oleh petani sagu di Desa Tanjung untuk dapat meningkatkan jumlah produksi sagu. Pada umumnya petani sagu mendapatkan modal berupa pinjaman, baik itu dari bank maupun lembaga keuangan lainnya, tetapi ada juga yang modalnya berasal dari modal pribadi.

Sedangkan nilai skor terendah dapat dilihat dalam menentukan akses sarana produksi dengan skor 3,50 yang kategori mandiri. Hal ini menunjukkan bahwa petani sagu di Desa Tanjung sudah mandiri dalam menentukan akses saranaproduksi. Penentuan akses sarana produksi di Desa Tanjung tidak tersedia seperti pengangkutan tual sagu, sehingga petani dalam menentukan akses 
sarana produksi yang akan digunakan yaitu menggunakan yang sudah diperoleh dari orang tua/kakek (turun temurun).

\section{Kemandirian Petani dalam Bekerjasama}

Mulyandari (2001), kemandirian petani dalam bekerjasama adalah kegiatan yang sama-sama menguntungkan seluruh anggota dengan dilandasi rasa saling percaya antar anggota serta menjunjung tinggi adanya norma yang berlaku.

Kemandirian petani dalam bekerja sama dapat dilihat pada Tabel 7. Tabel 7 menggambarkan secara keseluruhan kemampuan dalam bekerjasama petani di Desa Tanjung sudah mandiri, ini dapat dilihat dari rata-rata skor keseluruhan yaitu 3,91. Hal ini dikarenakan dengan adanya musyawah petani, petani sagu di Desa Tanjung sudah mandiri dalam meningkatkan usahataninya secara gotong royong/kerjasama dengan baik seperti, dalam pemanenan dilakukan secarara bergilir.

Tabel 7. Kemandirian petani dalam bekerja sama

\begin{tabular}{clcl}
\hline No & \multicolumn{1}{c}{ Indikator } & Skor & Kategori \\
\hline 1. & $\begin{array}{l}\text { Dasar pertimbangan } \\
\text { dalam bekerjasama }\end{array}$ & 3,95 & Mandiri \\
2. & $\begin{array}{l}\text { Mampu bekerjasama } \\
\text { dalam penyedian } \\
\text { jasa pertanian }\end{array}$ & 3,80 & Mandiri \\
3. & $\begin{array}{l}\text { Melaksanakan } \\
\text { kesepakatan } \\
\text { bekerjasama } \\
\text { Melaksanakan dan } \\
\text { mentati } \\
\text { perundangan yang } \\
\text { berlaku }\end{array}$ & 4,02 & Mandiri \\
\hline & 3,90 & Mandiri \\
Rata-rata & 3,91 & Mandiri \\
\hline
\end{tabular}

Sumber: Data olahan Tahun 2016

Secara keseluruhan kemandirian petani sagu tergolong kategori mandiri, namun apabila dilihat dari nilai skor masing-masing indikator, maka skor tertinggi terdapat pada melaksanakan kesepakatan bersama dengan skor 4,02 yang kategori mandiri. Hal ini membuktikan bahwa partisipasi petani di Desa Tanjung dalam beroganisasi sudah mandiri melaksanakan kesepakatan yang dibuat bersama. Kesepakatan bekerjasama dalam usahatani sagu di Desa Tanjung sesuai dengan kesepakatan petani. Kesepakatan ini biasanya dibuat ketika dilaksanakan rapat ataupun musyawarah. Kesepakatan bekerjama diputuskan setelah seluruh petani menyetujuinya.

Selanjutnya pada dasar pertimbangan dalam bekerja sama dengan skor 3,95 yang kategori mandiri. Dalam melakukan kerjasama petani di Desa Tanjung memiliki dasar pertimbangan adapun yang menjadi pertimbangan petani diantaranya adalah keterbukaan diantara sesama anggota kelompok tani, saling percaya, dan memiliki tujuan yang sama.

Begitu juga dengan melaksanakan dan mentaati perundangan yang berlaku dengan skor 3,90 dengan kategiri mandiri. Perundangundangan yang berlaku yang menyangkut kelompok tani sebelumnya sudah diberitahukan baik secara tertulis maupun secara lisan pada rapat kelompok tani. Pada umumnya Petani sagu di Desa Tanjung sudah mandiri dalam mentaati perundangan yang berlaku.

Sedangkan nilai skor terendah dapat dilihat pada kemandirian petani kemampuan bekerjasama dalam penyedian jasa pertanian dengan skor 3,90 dengan kategori mandiri. Dalam bekerjasama dalam penyediaan jasa pertanian petani sagu di Desa Tanjung melibatkan beberapa pihak, diantaranya adalah kelompok tani itu sendiri maupun dari Dinas Pertanian Kabupaten Kepulauan Meranti. Rendahnya nilai skor pada indikator ini dibandingkan indikator lainnya memberikan implikasi bagi petani untuk lebih meningkatkan kemandirian bekerjasamanya dalam penyediaan jasa pertanian.

\section{Kemandirian Mencari Informasi}

Mulyandari (2001), kemandirian mencari informasi yaitu melihat peluang yang memiliki manfaat atau kegunaan bagi seseorang bahkan orang yang banyak dan akan di pakai dalam pengambilan keputusan.

Kemandirian untuk mencari informasi dapat dilihat pada Tabel 8 . Tabel 8 menggambarkan secara keseluruhan bahwa kemandirian dalam mencari informasi sudah mandiri diperoleh rata-rata skor 3,90, Ini disebabkan karena desa tanjung tidak jauh dari kota sehingga informasi dengan mudah serta adanya peran kelompok tani kesulitan tersebut dapat diatasi. 
Tabel 8. Kemandirian petani sagu dalam mencari informasi

\begin{tabular}{clcl}
\hline No & \multicolumn{1}{c}{ Indikator } & Skor & Kategori \\
\hline 1. & $\begin{array}{l}\text { Mampu } \\
\text { mengoperasikan } \\
\text { teknologi }\end{array}$ & 3,92 & Mandiri \\
2. & $\begin{array}{l}\text { Mampu } \\
\text { mengetahui } \\
\text { peluang } \\
\text { 3ampu terus } \\
\text { menerus } \\
\text { memanfaatkan } \\
\text { informasi }\end{array}$ & 3,83 & Mandiri \\
& 3,90 & Mandiri \\
& & \\
\hline Rata-rata & 3,90 & Mandiri \\
\hline
\end{tabular}

Sumber: Data olahan Tahun 2016

Secara keseluruhan kemandirian petani sagu dalam mencari informasi tergolong kategori mandiri, namun apabila dilihat dari nilai skor masing-masing indikator, maka skor tertinggi terdapat pada mampu mengoperasikan teknologi dengan skor 3,92 dengan kategori mandiri. Petani sagu di Desa Tanjung sudah mandiri dalam mengopersikan teknologi, namun dalam mengoperasikan teknologi petani cukup kesulitan. Hal ini dikarenakan penyuluh pertanian yang merupakan orang yang berkewajian memberikan bantuan berupa informasi teknologi masih belum optimal dalam tugasnya. Berdasarkan temuan penulis juga bahwa, SDM petani yang masih konvensional dan belum sepenuhnya melakukan budidaya sagu secara arif dan bijak, ini dapat dilihat dari sisi pemeliharaan tanaman/kebun yang belum intensif. Disamping itu masih belum banyak masukan teknologi budidaya yang diterapkan dalam upaya peningkatan produksi dan produktivitas.

Selanjutnya mampu terus-menerus memanfaatkan informasi sudah mandiri dengan skor 3,90 dengan kategori mandiri. Petani sagu di Desa Tanjung tidak menyianyiakan informasi yang didapatkannya, informasi tersebut akan dimanfaatkan secara terus menerus. Informasi tersebut didapatkan, baik dari penyuluh pertanian maupun pengurus kelompok tani yang telah mengikuti pelatihan. Informasi yang didapat petani pada umumnya ketika ada rapat kelompok tani.

Sedangkan skor terendah dapat dilihat pada indikator mencari peluang 3,83. Hal ini menunjukkan bahwa petani sagu di Desa Tanjung dalam mengetahui peluang usahatani sudah mandiri. Artinya untuk mengetahui peluang usahatani, petani sagu tidak banyak memperoleh informasi. Kurangnya informasi dantingkat pendidikan serta tingkat pengetahuan yang rendah merupakan penghambat bagi petani sagu di Desa Tanjung dalam mencari peluang dalam berusahatani sagu. Ini memberikan implikasi bagi petani sagu di Desa Tanjung untuk dapat terus menggali informasi dan peluang berusahatani sagu.

\section{Pengetahuan Berusahatani}

Mulyandari (2001), tingkat pengetahuan petani adalah merupakan hasil yang terjadi setelah orang melakukan penginderaan terhadap suatu obyek tertentu. Tingkat pengetahuan petani dalam berusahatani sagu di lihat dari pengalaman berusahatani, tingkat pendidikan, mampu mengelola usahataninya, mampu memasarkan usahataninya ini dapat dilihat pada Tabel 9.

Tabel 9. Pengetahuan berusahatani

\begin{tabular}{|c|c|c|c|}
\hline No & Indikator & Skor & Kategori \\
\hline 1. & $\begin{array}{l}\text { Pengalaman } \\
\text { berusahatani }\end{array}$ & 4,23 & $\begin{array}{c}\text { Sangat } \\
\text { Mandiri }\end{array}$ \\
\hline 2. & Tingkat pendidikan & 3,38 & $\begin{array}{l}\text { Cukup } \\
\text { Mandiri }\end{array}$ \\
\hline 3. & $\begin{array}{l}\text { Mampu mengelola } \\
\text { usahatani }\end{array}$ & 3,70 & Mandiri \\
\hline 4. & $\begin{array}{l}\text { Mampu } \\
\text { memasarkan hasil } \\
\text { usahatani }\end{array}$ & 3,61 & Mandiri \\
\hline & Rata-rata & 3,73 & Mandiri \\
\hline
\end{tabular}

Sumber: Data olahan Tahun 2016

Tabel 9 di atas menggambarkan secara keseluruhan kemandirian dalam berusahatani yang tergolong kategori mandiri dengan skor rata-rata 3,73. Hal ini dikarenakan bahwa petani sagu di Desa Tanjung sudah memiliki ilmu dalam berusahatani yang mereka dapatkan secara turun temurun dari orang tua/kakek.

Secara keseluruhan indikator yang tertinggi adalah pengalaman usahatani yang tergolong kategori sangat mandiri dengan skor 4,23 . Hal ini menunjukkan bahwa petani sagu Desa Tanjung sudah memiliki pengalaman 
dalam berusahatani. Pengalaman usahatani tersebut diperoleh secara turun temurun, Berdasarkan hasil survey juga menunjukkan bahwa petani sagu Desa Tanjung pada umumnya memiliki pengalaman usahatani > 10 tahun.

Selanjutnya indikator yang tergolong mandiri dapat dilihat pada indikator mampu mengelola usahatani dengan skor 3,70 yang tergolong kategori mandiri. Hal ini menunjukkan bahwa petani di Desa Tanjung sudah mandiri dalam pengelolaan tanaman sagu. Namun dalam pelaksanaannya banyak hambatan, diantaranya hambatan yang berasal dari petani itu sendiri, misalnya kurangnya tingkat pengetahuan petani dalam memanfaatkan faktor peroduksi yang ada untuk digunakan secara efektif dan efisien agar mendapatkan keuntungan yang maksimal. Selain itu, faktor modal juga menjadi hambatan dalam pengelolaan usahatani sagu. Begitu juga dengan mampu memasarkan hasil usahatani dengan skor 3,61 yang tergolong kategori mandiri. Hal ini menunjukkan bahwa petani sagu Desa Tanjung dalam memasarkan hasil usahatani sagu sudah mandiri. Pada umumnya petani sagu, mulai dari panen sampai memasarkan usahataninya dilakukan secara mandiri.

Sedangkan indikator yang tergolong kategori cukup mandiri dapat dilihat dari tingkat pendidikan petani dengan skor 3,38 yang tergolong kategori cukup mandiri. Artinya bahwa tingkat pendidikan cukup banyak mempengaruhi pengetahuan berusahatani, seperti diketahui bahwa tingkat pendidikan petani sagu di Desa Tanjung pada umumnya adalah SD, dengan tingkat pendidikan tersebut masih belum cukup pengetahuan petani tentang pengembangan tanaman sagu, pengunaan bibit unggul dan bagaimana pemberantasan hama menyebabkan hasil yang didapat dari pengelolaan tanaman sagu menjadi tidak maksimal. Kurang optimalnya dari segi tingkat usahatani karena petani sagu pada umumnya beranggapan bahwa untuk mengusahakan sagu tidak memerlukan pendidikan yang tinggi.

\section{Rekapitulasi Kemandirian Petani Sagu di Desa Tanjung}

Secara keseluruhan variabel kemandirian petani sagu di Desa Tanjung, Kecamatan
Tebing Barat, Kabupaten Kepulauan Meranti dilihat dari kemandirian untuk mengambil keputusan dalam pemilihan jenis komoditi, penentuan harga komoditi yang dihasilkan, akses sarana produksi pertanian, mencari informasi, pengetahuan tentang berusahatani, kemandirian dalam pengetahuan berusahatani, dapat direkapitulasi seperti pada Tabel 10 .

Tabel 10 menggambarkan secara keseluruhan bahwa kemandirian petani sagu dalam berusahatani sagu di Desa Tanjung sudah mandiri, ini dapat dilihat dari skor ratarata yang diperoleh yaitu 3,75 yang tergolong kategori mandiri. Apabila dilihat kategori maka kategori yang tergolong mandiri terdapat sub variabel kemandirian untuk mengambil keputusan dalam pemilihan jenis komoditi sagu yang diusahakan sudah mandiri dengan skor rata-rata 3,84.

Tabel 10. Rekapitulasi kemandirian petani dalam berusahatani sagu

\begin{tabular}{clcc}
\hline No & \multicolumn{1}{c}{ Sub Variabel } & Skor & Kategori \\
\hline 1. & $\begin{array}{l}\text { Kemandirian untuk } \\
\text { mengambil keputusan } \\
\text { dalam pemilihan jenis } \\
\text { komoditi }\end{array}$ & 3,84 & Mandiri \\
2. & $\begin{array}{l}\text { Penentuan harga } \\
\text { komoditi } 3,38 \\
\text { dihasilkan yang }\end{array}$ & $\begin{array}{l}\text { Cukup } \\
\text { mandiri }\end{array}$ \\
3. & $\begin{array}{l}\text { Penentuan sarana } \\
\text { produksi pertanian }\end{array}$ & 3,74 & Mandiri \\
4. & $\begin{array}{l}\text { Kemandirian petani } \\
\text { dalam bekerjasama }\end{array}$ & 3,91 & Mandiri \\
5. & $\begin{array}{l}\text { Mencari informasi } \\
\text { Kemandirian dalam }\end{array}$ & 3,90 & Mandiri \\
pengetahuan & Mandiri \\
berusahatani & & \\
\hline & Rata-rata & 3,75 & Mandiri \\
\hline
\end{tabular}

Sumber: Data olahan Tahun 2016

Hal ini ditunjang oleh penentukan jenis komoditi yang diusahakan, dasar pertimbangan dalam pemilihan jenis komoditi, dan pihak yang terlibat dalam pemilihan komoditi, artinya petani mempunyai inisiatif dan memutuskan sendiri, terutama untuk pilihan komoditi sagu yang diusahakan.

Kemandirian petani dalam mengambil keputusan dalam pemenuhan sarana produksi sudah mandiri memperoleh skor rata-rata 3,74. Hal ini ditunjang dengan menentukan akses sarana produksi, dasar pertimbangan dalam 
penentuan sarana produksi, dan pihak yang terlibat dalam proses penentuan sarana produksi, hal ini membuktikan bahwa petani sagu di Desa Tanjung sudah memiliki sarana yang akan digunakan yang diperoleh dari orang tua/kakek (turun temurun) dan tidak tergantung kepada orang luar/toke.

Kemandirian dalam bekerjasama petani di Desa Tanjung sudah mandiri, ini dapat dilihat dari rata-rata skor keseluruhan yaitu 3,91. Hal iniditunjang dengan adanya, dasar pertimbangan dalam bekerjasama, mampu bekerjasama dalam penyediaan jasa pertanian melaksanakan kesepakatan, serta bekerjasama melaksanakan dan mentaati perundangan yang berlaku, ini dikarenakan dengan adanya musyawah pada petani sagu di Desa Tanjung dengan persetujuan bersama dalam meningkatkan usahataninya secara gotong royong/kerjasama dengan baik seperti, dalam pemanenan dilakukan secarara bergilir.

Kemandirian dalam mencari informasi sudah mandiri diperoleh rata-rata skor 3,90. Ini ditunjang dengan kemampuan mengoperasikan teknologi, mampu mengetahui peluang, serta mampu terus menerus memanfaatkan informasi. Hal ini disebabkan karena desa tanjung tidak jauh dari kota sehingga informasi dengan mudah serta adanya peran kelompok tani sehingga kesulitan tersebut dapat diatasi.

Kemandirian dalam berusahatani yang tergolong kategori mandiri dengan skor ratarata 3,73. Hal ini di tunjang dengan adanya pengalam berusaha tani, mampu mengelola usaha tani, dan mampu memasarkan hasil usaha tani, hal ini dikarenakan bahwa petani sagu di Desa Tanjung sudah memiliki ilmu dalam berusahatani yang mereka dapatkan secara turun temurun dari orang tua/kakek.

Sedangkan sub variabel yang tergolong cukup mandiri adalah kemandirian petani mengambil keputusan dalam penentuan harga cukup mandiri dengan skor rata-rata 3,38. Hal ini dikarenakan oleh dasar pertimbangan dalam penentuan harga komoditi, dan pihak yang terlibat dalam proses penentuan harga komoditi, petani dan toke/tengkulak yang saling tawar-menawar harga walaupun toke/tengkulak sudah menentukan/mematok harganya.

\section{KESIMPULAN DAN SARAN}

\section{Kesimpulan}

Kemandirian petani sagu di Desa Tanjung dilihat dari kemandirian dalam pemilihan jenis komoditi yang diusahakan, penentuan harga komoditi yang dihasilkan, akses sarana produksi pertanian, kemampuan dalam bekerja sama, kemampuan untuk mencari informasi, dan pengetahuan dalam berusahatani tergolong mandiri, dapat disimpulkan:

1) Rata-rata kemandirian petani dalam berusaha tani adalah mandiri dengan skor 3,75 .

2) Dalam berusahatani sagu petani sudah mandiri dalam mengambil keputusan pemilihan jenis komoditi, akses sarana produksi, kemandirian petani dalam bekerja sama, mencari informasi, dan pengetahuan dalam berusaha tani.

3) Petani sagu baru berada pada kategori cukup mandiri dalam penentuan harga komoditi yang dihasilkan.

\section{Saran}

Mengambil keputusan pemilihan jenis komoditi, akses sarana produksi, kemandirian petani dalam bekerja sama, mencari informasi, dan pengetahuan dalam berusaha tani. Untuk itu hal-hal tersebut perlu lebih ditingkatkan lagi kemandirian petani sagu di Desa Tanjung dari mandiri menjadi sangat mandiri. Peran pemerintah Kabupaten Kepulauan Meranti sangat diperlukan agar petani lebih mandiri lagi dalam berusahatani sagu, misalnya mengoptimalkan peran penyuluh pertanian dalam usaha meningkatkan produksi dan produktivitas petani serta menyalurkan bantuan modal untuk petani sagu supaya petani sagu di Tebing Tinggi Barat tidak memiliki ketergantungan dengan touke dalam penentuan harga komoditi yang dihasilkan.

\section{DAFTAR PUSTAKA}

Anantanyu. (2008). Tipe petani dan strategi pengembangan kelembagaan kelompok petani (Kasus di Provinsi Jawa Tengah). Jurnal Penelitian M Power, 8(8), 34-48.

Dinas Perkebunan Dan Kehutanan Kabupaten Kepulauan Meranti. 2014. Statistik 
Perkebunan Kepulauan Meranti 2014. Kepulauan Meranti. Riau.

Ediningtyas, D. (2007). Kemandirian masyarakat desa sekitar hutan dalam melakukan usaha agroforestry: Studi kasus usahatani agroforestry tanaman kopi di BPKH Pangalengan, KPH Bandung Selatan, Perum Perhutani Unit III, Jawa Barat Banten. (Tesis). Program Studi Ilmu Penyuluhan Pembangunan, Sekolah Pascasarjana Institut Pertanian Bogor, Bogor

Lestari, M. 2011. Dinamika Kelompok Dan Kemandirian Anggota Kelompok Tani Dalam Berusahatani Di Kecamatan Poncowarno Kabupaten Kebumen Propinsi Jawa Tengah. Program Pasca Sarjana Universitas Sebelas Maret Surakarta.
Mulyandari, RSH. 2001. Faktor-Faktor Yang Mempengaruhi Pengembangan Kemandirian Petani melalui Penyuluhan (Kasus Desa Ciherang Kecamatan Dermaga Kabupaten Bogor, Jawa Barat). Tesis. Bogor: IPB.

Rosnita 2016. Dampak kemandirian penyuluh terhadap keberdayaan petani kelapa sawit pla swadaya di Provinsi Riau. Jurnal Ilmiah Agribisnis Faperta Universitas Riau. Riau

Sugiyono. 2006. Metode Penelitian Bisnis. Salemba Empat. Jakarta: Aida Vitayala.

Subagio, H. (2008). Peran kapasitas petani dalam mewujudkan keberhasilan usahatani: Kasus petani sayuran dan padi di Kabupaten Malang dan Pasuruan, Provinsi Jawa Timur. (Disertasi). Departemen Komunikasi dan Pengembangan Masyarakat, Sekolah Pascasarjana Institut Pertanian Bogor, Bogor. 